Linköping Studies in Science and Technology. Theses No. 1778 Licentiate Theses

\title{
Asset Liability Management for Tanzania Pension Funds
}

\author{
Mwakisisile, Andongwisye John
}

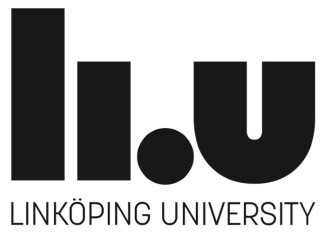

Department of Mathematics, Division of Optimization Linköping University, SE-581 83 Linköping, Sweden

Linköping 2018 
Linköping Studies in Science and Technology. Theses No. 1778

Asset liability management for Tanzania pension funds

Copyright (C) Mwakisisile, Andongwisye John, 2018

Division of Optimization

Department of Mathematics

Linköping University

SE-581 83, Linköping, Sweden

andongwisye.john@liu.se

www.mai.liu.se

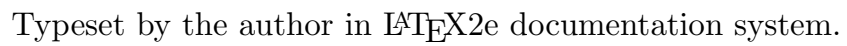

ISSN 978-91-7685-512-6

ISBN 0280-7971

Printed by LiU-Tryck, Linköping, Sweden 2018 


\section{Abstract}

This thesis presents a long-term asset liability management for Tanzania pension funds. As an application, the largest pension fund in Tanzania is considered. This is a pay-as-you-go pension fund where the contributions are used to pay current benefits. The Pension plan analyzed is a final salary defined benefit. Two kinds of pension benefit are considered, a commuted (at retirement) and a monthly (old age) pension. A decision factor in the analysis is the increased life expectancy of the members of the pension fund.

The presentation is divided into two parts. First is a long-term projection of the fund using a fixed and relatively low return on asset value. Basing on the number of members in 2015, a 50 years projection of members and retirees is done. The corresponding amount of contributions, asset values, benefit payouts, and liabilities are also projected. The evaluation of some possible reforms of the fund is done. Then, the growth of asset values using different asset returns is studied. The projection shows that the fund will not be fully sustainable in a long future due to the increase in life expectancy of its members. The contributions will not cover the benefit payouts and the asset value will not fully cover liabilities. Evaluation of some reforms of the fund shows that they cannot guarantee a long-term sustainability. Higher returns on asset value will improve the asset to liability ratio, but contributions are still insufficient to cover benefit payouts.

Second is a management based on stochastic programming. This approach allocates investment in assets with the best return to raise the asset value closer to the level of liabilities. The model is based on work by Kouwenberg in 2001 includes some features from Tanzania pension system. In contrast with most asset liability management models for pension funds by stochastic programming, liabilities are modeled by number of years of life expectancy. Scenario trees are generated by using Monte Carlo simulation. Two models according to different investment guidelines are built. First is using the existing investment guidelines and 
second is using modified guidelines which are practical and suitable for modeling. Numerical results suggest that, in order to improve a long-term sustainability of the Tanzania pension fund system, it is necessary to make reforms concerning the contribution rate, investment guidelines and formulate target levels (funding ratios) to characterize the pension funds' solvency situation. These reforms will improve the sustainability of the system. 


\section{Populärvetenskaplig sammanfattning}

Denna avhandling behandlar långsiktig kapitalförvaltning för den största pensionsfonden i Tanzania. Fonden använder inbetalda avgifter från medlemmar i yrkeaktiv ålder till att betala pensioner till nuvarande förmånstagare, vilka främst är ålderspensionärer. Pensionens storlek är avgiftsbestämd, vilket innebär att den utbetalade pensionen avgörs av medlemmens lön under de yrkesaktiva åren. Pensionen består av två delar: dels ett större belopp som utbetalas då medlemmen går i pension och dels en månatlig pension under återstoden av livet. De inbetalda avgifter som inte förbrukas till pensionsutbetalningar sparas och investeras för framtida behov. Den långsiktiga hållbarheten hos ett pensionsystem av denna typ avgörs av många faktorer, men en avgörande faktor är utvecklingen hos den förväntade livslängden bland fondens medlemmar.

Avhandlingen ger först en prognos för fondens utveckling under en tidshorisont på 50 år, utifrån de nu gällande reglerna för pensionsystemet, såsom avgifternas storlek och pensionsåldern, och förväntade förändringar i Tanzanias samhällsekonomi, framförallt demografisk sammansättning och ökande livslängd. Denna prognos visar att pensionssystemet kommer att fungera väl under lång tid och accumulera stora överskott i fonden. Mot slutet av tidshorisonten kommer dock en avstannande befolkningstillväxt tillsammans med den ökande livslängden göra att pensionsutbetalningarna kraftigt överstiger de inbetalade avgifterna, varför fondens sparade kapital snabbt förbrukas, vilket innebär att systemet inte är långsiktigt hållbart. I avhandlingen görs vidare prognoser för effekterna av några tänkbara åtgärder för att förbättra hållbarheten, såsom höjda pensionsavgifter och höjd pensionsålder, eller att fonden investerar sitt kapital så att det ger högre avkastning. De effekter som uppnås visar dock att ingen enskild åtgärd räcker för att signifikant öka systemets långsiktiga hållbarhet. Istället måste flera åtgärder kombineras för att uppnå detta.

Ett viktigt medel för att öka den långsiktiga hållbarheten hos ett pensionssystem av denna typ är att säkerställa hög och säker avkastning på fondens kapital. Avhandlingen ger en stokastisk optimeringsmodell för detta syfte, anpassad till de förutsättningar som gäller i Tanzania. En sådan modell beaktar en lång planeringshorisont och olika placeringsalternativ, som till exempel aktier, obligationer och fastigheter, och tar hänsyn till att dessa har olika förväntad avkastning och risk. Osäkerheten i utfallet av olika investeringar modelleras med hjälp av ett stort antal möjliga scenar- 
ier för utvecklingen hos avkastningen under planeringshorisonten, och där varje framtida scenario inträffar med en viss sannolikhet. Modellen ger som resultat en placeringsstrategi som ger maximal förväntad avkastning givet att risken hålls på en acceptabelt låg nivå. Resultat för den tanzaniska pensionsfonden visar att det bör vara möjligt att öka dess avkastning avsevärt, genom en mer flexibel placeringsstrategi än vad som används idag. 


\section{Acknowledgment}

First, I would like to express my deepest gratitude to my supervisors Prof. Torbjörn Larsson and Ass. Prof. Martin Singull for their valuable guidance, encouragement and insightful ideas. Thank you Torbjörn, thank you Martin. I have learned a lot from you, You have not only benefited me but my country. I would like to express my appreciation to my home supervisor Prof. Allen Mushi for his encouragement and advice during my studies.

I would like to thank ISP through EUMP for giving me this opportunity to attend studies here at Linköping University. Your generous and kind to support Africa especially Tanzania is appreciated.

My deep gratitude goes to all members of the department of Mathematics at Linköping University, for their constant help. I thank my fellow PhD students at the department of mathematics for making life easier during my studies. Also to all members of optimization group. You have contributed a lot in my studies. I am very happy to join this family.

I am thankful to my colleagues at department of mathematics at University of Dar es salaam especially the head of department Eunice Mureithi, former head of department Estomic Massawe and former EUMP coordinator Sylvester Rugeihyamu for their invaluable contribution to the smooth running of my studies.

I would like to thank all my family members especially my dear father John Isaack Mwakisisile. You have been part of my success with courage, guidance, and prayers. My late mother Theresia Isaack who passed away during my studies, may almighty God rest her soul in peace. Thank you mummy, I will never forget your advice.

Finally, I would like to thank my dearest wife Evelyn. You have been with me making sure that I do not miss your close companion. My son Uswege, my daughters Sekela, Ndimbumi, Ndigwako and Tupokigwe, thank you very much. 


\section{Contents}

1 Introduction $\quad 1$

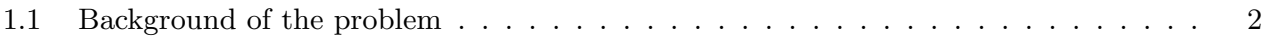

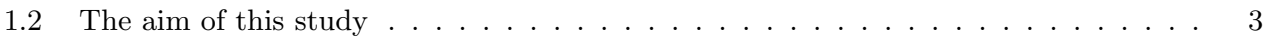

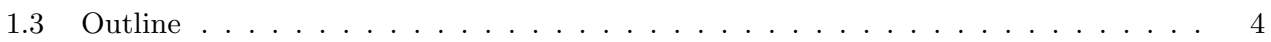

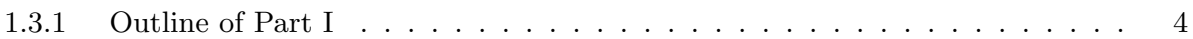

1.3.2 Outline of Part II . . . . . . . . . . . . . . . . . . 4

2 Asset liability management for pension funds $\quad 9$

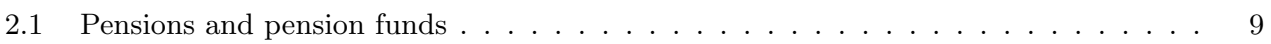

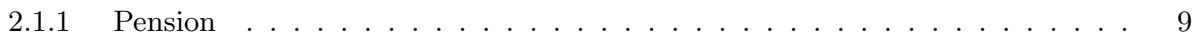

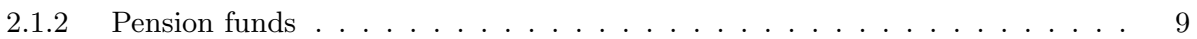

2.1 .3 Pension schemes or plans . . . . . . . . . . . . . . . . . . 9

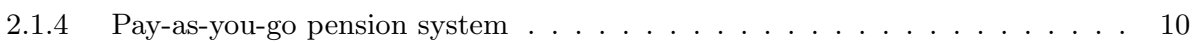

2.2 Elements of asset liability management for pension funds . . . . . . . . . . . . 10

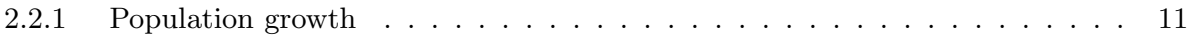

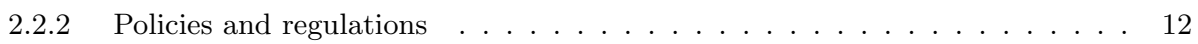

2.3 Pension system in Tanzania . . . . . . . . . . . . . . . . . . . . . 13

3 Literature review $\quad 15$

3.1 Stochastic programming . . . . . . . . . . . . . . . . . 15

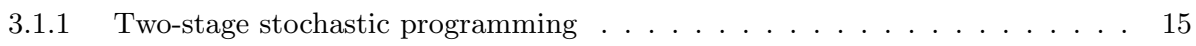

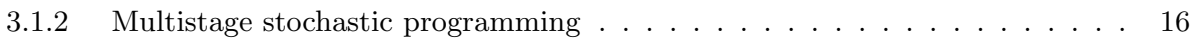

3.1 .3 Risk constrained . . . . . . . . . . . . . . . . . . 16

3.2 Scenario tree . . . . . . . . . . . . . . . . . . . . . . . 19

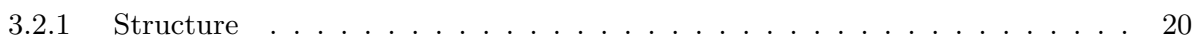

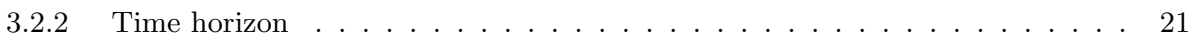

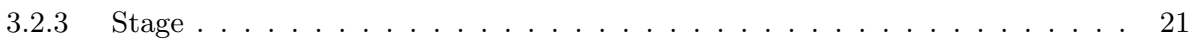

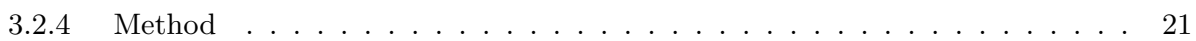

4 Concluding Remarks $\quad 25$

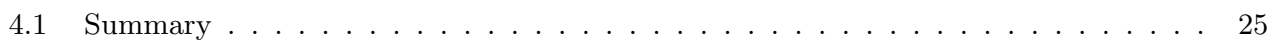

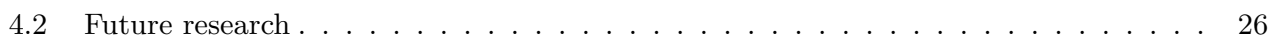

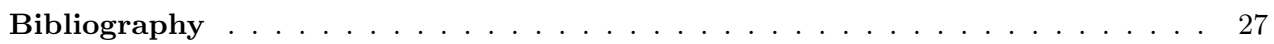


A. Projection of Tanzania pension system $\quad 33$

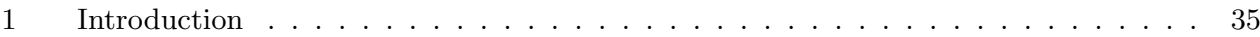

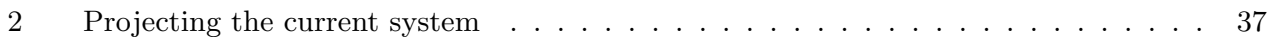

$2.1 \quad$ Projecting members and retirees $\ldots \ldots \ldots \ldots \ldots$

2.2 Contributions, benefits, benefits payout, cash flow . . . . . . . . . . 41

2.3 Asset value and liabilities . . . . . . . . . . . . . . . . 45

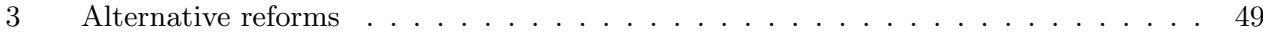

3.1 Increase the contribution rate to $25 \%$ after 20 years . . . . . . . . . . 50

3.2 Increase retirement age to 65 years after 20 years $\ldots \ldots \ldots \ldots$. . . . . 52

3.3 Increase both contribution rate and retirement age after 20 years . . . . . 53

4 Effect of interest rate . . . . . . . . . . . . . . . . . . . . 54

B. Asset liability management for Tanzania pension funds by stochastic programming $\quad \mathbf{5 7}$

$1 \quad$ Introduction $\ldots \ldots \ldots \ldots \ldots \ldots \ldots \ldots \ldots \ldots$

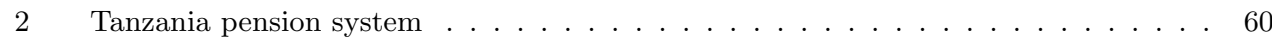

3 Asset liability management for pension funds by stochastic programming . . . . . . 61

$3.1 \quad$ Multistage stochastic programming . . . . . . . . . . . . . . . . 61

3.2 Scenario tree . . . . . . . . . . . . . . . . . . 63

3.3 Application to asset liability management for pension funds . . . . . . . . . 64

4 Problem formulation . . . . . . . . . . . . . . . . . . . . . 65

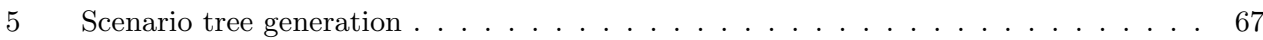

$5.1 \quad$ Asset return scenarios . . . . . . . . . . . . . . . . 67

$5.2 \quad$ Liability scenarios . . . . . . . . . . . . . . . . . . . . 68

6 Numerical results . . . . . . . . . . . . . . . . . . . . . . . . . 69

$6.1 \quad$ Generating scenario trees . . . . . . . . . . . . . . . . . . 69

$6.2 \quad$ Main results . . . . . . . . . . . . . . . . . . . . 71

6.3 First case: using current investment guidelines . . . . . . . . . . . . . 72

6.4 Second case: using modified investment guidelines . . . . . . . . . . . . . . 74

6.5 Increasing contribution rates . . . . . . . . . . . . . . . 77

6.6 The effect of funding ratio on fund's sustainability $\ldots \ldots \ldots \ldots$

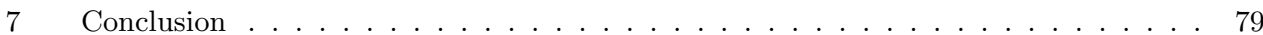





\section{Introduction}

Asset liability management (ALM) for pension funds is a risk management approach, which takes into account the assets, the liabilities, and different policies and regulations. The management of a pension fund should find acceptable policies that guarantee with a large probability that the solvency of the fund is sufficient during the planning horizon and, at the same time, all benefit payouts can be made. Management of assets involve decisions on the investment of portfolio while the liability consists of future pension payments [21].

When modeling optimization problems, we can use a deterministic approach, where parameters are known at the time of making the decision, or stochastic programming in which the parameters are not known (uncertain) at the time of making the decision. The goal of stochastic programming is to find optimal decision policies in problems involving uncertain data. In this terminology, stochastic is opposed to deterministic, whereas programming refers to the fact that various parts of the problem can be modeled as linear or nonlinear mathematical program [5].

Stochastic programming has been proven to be an efficient approach in designing effective strategies in wealth and asset liability management in practice [23]. In pension funds, future assets returns, liabilities, streams of contributions and benefits are unknown. An application of stochastic programming means that these uncertainties are modeled as random parameters in a discrete time model with a finite planning horizon [18].

Scenario trees are used in stochastic programming to describe the uncertainty of parameters in the discrete-time setting. The scenario tree branches off every random parameter in each time stage. This approach requires a finite discrete distribution that is limited in a number of possible values of the random parameters. According to [31], the performance of stochastic programming can be improved by choosing an appropriate scenario generation method.

In this thesis, the focus is on asset liability management for Tanzania pension funds which are pay-as-you-go schemes. Using the largest pension fund in Tanzania, a 50 years projection of fund's members, retirees, contributions, asset values, benefit payouts and liabilities is done. Evaluation 
of some possible pension fund reforms is studied. Also, the effect of return on asset of the fund is analysed. The projection shows that the fund will not be fully sustainable in a long term period.

Using a stochastic programming approach, two models according to different investment guidelines are built, the current and modified investment guidelines. Numerical results suggest that, in order to improve a long-term sustainability of the Tanzania pension fund system, it is necessary to make reforms concerning the contribution rate, investment guidelines and formulate target levels (funding ratios) to characterize the pension funds' solvency situation.

\subsection{Background of the problem}

Pay-as-you-go pension is a system where current benefit payouts for retirees are paid by the contributions from the current members. It requires a balance between the benefits paid to the retirees and the contributions made by the active members. The system is much affected when the old population exceed the working population. Several studies have been conducted which show that the world demography is changing rapidly with increased life expectancy (decrease mortality rate) and decreased fertility rate. The works of [3], [6], [7], [11], [30] and [41] argue that in the past time the world population experienced short life, births were many, population growth was slow and population was young. Recently, the mortality and fertility rates have declined, causing population growth, lower working population growth, long life and an old population. The decreasing ratio of working population to retirees is bringing various policy responses. Parametric reforms tinker with pay-as-you-go defined benefit pension schemes by reducing benefits, raising taxes and eliminating the incentives for early retirement.

Sweden, Italy and Germany have introduced notional defined contribution (NDC) pension systems [9], whereby pay-as-you-go systems mimic the defined contribution plan. The NDC pension system removes incentives for early retirement and passing on to individual retirees the financial risks of rising longevity. In [36], the problem and prospects that face pay-as-you-go pension funds in Greece are studied. Considering the demography changes, it shows that the system will not work unless some reforms are done.

Also, [26] studied a sustainability framework for pay-as-you-go pension system. The study forecasts that the net present value of expenditure on pensions in the US will exceed the net present value of contributions through the period 2015 - 2089. Moreover [29] developed a benchmark risk measure for pension sponsors by obtaining a total asset requirement for sustaining the pension plan due to increasing the risk of increased longevity.

Due to the increase of an old population, [23] and [19] studied the asset liability management by stochastic programming for a Finnish insurance company and an Austrian pension fund, respec- 
tively. Pension fund's contributions, asset returns, benefits and liabilities are uncertain. Stochastic programming is used as a decision method of finding an optimal decision considering investment policies.

\subsection{The aim of this study}

The theme of this thesis is the future sustainability of the Tanzania pension system. The system comprises of five mandatory pension funds which are Parastatal Public Pension (PPF), Public Service Pension Fund (PSPF), National Social Security Fund (NSSF), Local Authorities Pension Fund (LAPF) and Government Employees Provident Fund (GEPF). With the exception of the GEPF, all pension funds are operating on pay-as-you-go defined benefit basis. These funds are regulated and supervised by Social Security Regulatory Authority (SSRA). The system faces a gradual increase of members' life expectancy (which is linked to longevity risk). According to [38], the system in 2014 seemed to be sustainable, although not fully sustainable over the long term. The system dependency ratio (the number of retirees divided by a number of contributors) was low, about $7 \%$ on average. Though this does vary significantly from as little as $1 \%$ in NSSF to over $22 \%$ in PPF, depending on the degree of scheme maturity. This means that the financial burden on each contributor was low. But as the system matures this ratio will grow fast. Some of the pension funds like PSPF has already started to experience the effect of increased life expectancy [28]. Further parametric reforms will be required in future to assure the long-term viability of the system.

The largest pension fund in Tanzania is NSSF. The NSSF has more members than other funds (about $44 \%$ of the total pension funds population in 2014/2015 by SSRA records). Also, it has lowest retirees to contributors dependency ratio. The NSSF was established by the Act of Parliament No. 28 of 1997 to replace the defunct National Provident Fund (NPF). It is a compulsory scheme providing a wider range of benefits which are based on internationally accepted standards, and it is a formal institution that provides social security protection in Tanzania. It offers social security coverage to employees of private sector and non-pensionable Parastatal organizations, government employees, self-employed or any other employed person not covered by any other fund and any other category as declared by the Minister of Labour. It is a fully funded scheme running under defined benefit principles. Surplus of the fund collected after paying members benefit are invested for the purpose of finacing future benefit payments and operation costs.

In this thesis, the projection of the fund in a period of 50 years is done. Assuming an open pension system where new members are recruited every year, the future number of members and retirees are analyzed using different mortality rates of working population and life expectancy. Future amounts of contributions, asset values, benefit payouts and liabilities are also projected. 
Two stochastic programming models are built. The sequence of decisions (asset allocations, contribution rates) is made for the horizon of 50 years in stages. Asset categories used are government securities, real estate, loans and deposits with their corresponding returns from NSSF annual reports of $2001-2011$. The objective is to minimize the total expected contribution rates for active participants and sponsors of the fund.

\subsection{Outline}

This thesis contains two part and the outline is as follows.

\subsubsection{Outline of Part I}

This part contains two chapters which explain the basic concepts of asset liability management for pension funds and a review of some studies done in selected countries. Chapter 2 gives the definitions of parameters applied in asset liability management for pension funds. Important elements for asset liability management for pension fund are discussed. In Chapter 3 a literature review of different models of stochastic programming applied in asset liability management for pension funds in selected countries is given.

\subsubsection{Outline of Part II}

This part consists of two papers. The second paper is founded on the analysis done in the first paper. Hereafter is the abstracts of the papers.

\section{Paper 1}

John A., Larsson T., Singull M., and Mushi A. (2017). Projection of Tanzania pension system

In this paper, a final salary defined benefit for mandatory Tanzania pension fund is studied. This fund is a contributory pay-as-you-go defined benefit pension system where the retirement benefits are financed by contributions collected from current members. It is much affected by change in demography. Two kinds of pension benefit, a commuted (at retirement) and a monthly (old age) pension are considered. A decision factor in the analysis is the increased life expectancy of members of the fund. The projection of the fund's future members and retirees is done using mortality rates of working population and expected life expectancy. The future contributions, benefits, asset value and liabilities are analyzed. The projection shows that the fund will not be fully sustainable in a long future due to the increase in life expectancy of its members. The contributions will not cover the benefit payouts and the asset value will not fully cover liabilities. Evaluation of some possible 
reforms of the fund shows that they cannot guarantee a long-term sustainability. Higher returns on asset value will improve the asset to liability ratio, but contributions are still insufficient to cover benefit payouts.

Contribution: The research problem for this paper was suggested by my supervisors. This paper is the product of multiple discussion between the first author and co- authors. The first author suggested the title, doing all detailed calculations, coding, simulations and writing of the paper.

\section{Paper 2}

John A., Larsson T., Singull M., and Mushi A. (2017). Asset liability management for Tanzania pension fund by stochastic programming

This paper presents a long-term model of asset liability management for Tanzania pension funds. The pension system is pay-as-you-go where contributions are used to pay current benefits. The pension plan is a final salary defined benefit. Tanzania pension funds face an increase of its members' life expectancy where the retirees to contributors dependency ratio will increase. Two kinds of pension benefit are considered, a commuted (at retirement) and a monthly (old age) pension. A decision factor is the increased life expectancy of the members of the pension fund. Stochastic programming approach allocates assets with the best return to raise the asset value closer to the level of liabilities. A model is based on work by Kouwenberg in 2001, with some features from Tanzania pension system. In contrast with most asset liability management models for pension funds by stochastic programming, liabilities are modeled by using number of years of life expectancy for monthly benefit. Scenario trees are generated using Monte Carlo simulation. Numerical results suggest that, in order to improve a long-term sustainability of the Tanzania pension fund system, it is necessary to make reforms concerning the contribution rate, investment guidelines and formulate target levels (funding ratios) to characterize the pension funds' solvency situation. These reforms will improve the sustainability of the system.

Contribution: The research problem for this paper was suggested by the first author. This paper is the product of multiple discussion between the first author and co- authors. The first author suggested the title of the paper, doing all detailed calculations, coding, simulations and writing of the paper. 



\section{PART I}





\section{Asset liability management for pension funds}

The purpose of this chapter is to give the overview of basic concepts and terminologies which are used in the subsequent chapters of this thesis.

\subsection{Pensions and pension funds}

\subsubsection{Pension}

A pension is a fixed amount, other than a wage, paid in terms of benefit as a lump sum or at regular intervals to a person or to the person's surviving dependents in consideration of past services, age, merit, poverty and injury or loss sustained [16].

\subsubsection{Pension funds}

Pension funds are considered to be organizations that have been set the task to make benefit payments to people that have ended their active career. The payments to be made to the retirees must be in accordance with the benefit formula that prescribe the flow of payments to which each member in the fund is entitled [14].

\subsubsection{Pension schemes or plans}

There are two major kinds of pension schemes, defined contribution and defined benefit as described in $[15]$. 


\section{Defined contribution}

A defined contribution scheme specifies how much a member will contribute, often a fixed percentage of salary. The fixed percentage of the salary is called contribution rate. The benefit is determined by the size of accumulated contributions in an individual account who participate in a profit sharing. At an agreed age or state, pension benefits are paid as a lump sum or as regular payments basing on the accumulated wealth into an individual account of the participant. The payments are calculated by actuarial techniques and the employee bears a financial investment risk.

\section{Defined benefit}

A defined benefit scheme specifies a level of benefit, usually salary in relation near retirement (final salary), or to salary throughout employment (career average salary plans). This level is usually defined according to a benefit formula as a function of the salary and years of the service. Investment financial risks associated with defined benefit are borne by the plan sponsor. A sponsor is obliged to provide adequate funds to cover any liability's deficit.

\subsubsection{Pay-as-you-go pension system}

A pay-as-you-go (PAYG) pension system refers to a plan in which the current pension of the retirees is financed by contributions from current members. Usually, the benefit is calculated according to a formula based on employee's salary and years of the service. This system is adopted by most public pension funds. With a young population, it is attractive as the contribution rate is low and the current retirees get benefits immediately. However, when the population is ageing and the rate of old population is higher than working population growth, the amount of contributions cannot catch up with the promised benefit payouts. In that situation, the system is not sustainable unless the amount of benefit to retirees decreases or the contributions to current members increases (e.g., increasing tax rate) [32].

\subsection{Elements of asset liability management for pension funds}

Asset liability management of pension funds is the periodic decision on how the diversification of investments portfolio over different asset categories is done. The decision must be restricted by different regulations and policies that the management of pension fund can apply in order to meet obligations. There are several elements important for asset liability management for pension funds. 


\subsubsection{Population growth}

Population growth is a key element of asset liability management problems for pension funds. The calculation should use the current population to project the future population. A pension fund planning horizon can be some decades due to the long commitment to members. Based on [33], we consider transition matrix $\Pi$ for $n$ different states which include ages of active members, inactive members, retirement and dead defined as

$$
\Pi=\left[\begin{array}{cccccccccc}
\pi_{11} & \pi_{12} & 0 & 0 & 0 & 0 & \ldots & \pi_{1 n-2} & \pi_{1 n-1} & \pi_{1 n} \\
0 & \pi_{22} & \pi_{23} & 0 & 0 & 0 & \ldots & \pi_{2 n-2} & \pi_{2 n-1} & \pi_{2 n} \\
\vdots & \vdots & \vdots & \vdots & \vdots & \vdots & \ddots & \vdots & \vdots & \vdots \\
0 & 0 & 0 & 0 & 0 & 0 & \ldots & \ldots & \ldots & 1
\end{array}\right]
$$

Here, $\pi_{i j}$ is the portion that moves from state $i$ to state $j$ where

$$
\begin{array}{r}
\pi_{i j} \geq 0 \quad \forall i, j \in 1, \ldots, n \\
\sum_{j \in Z} \pi_{i j}=1 \quad \forall i \in 1, \ldots, n .
\end{array}
$$

The columns and rows represent states of the fund. It is possible for a survivor to move to the subsequent state. But in each state, there is the risk of dying. Each year the model moves a member to the next age or to death. If the age is near retirement, the model moves a survivor to retirement state. There are four possibilities, moves to next age, inactive, die or retire for those ages approach retirement.

Using the matrix $\Pi^{T}$ as the transpose matrix of $\Pi$, the population at time $t$ is a vector $P_{t}$ given by the relation

$$
P_{t}=\Pi^{T} P_{t-1}
$$

if the system does not allow new members, and

$$
P_{t}=\Pi^{T} P_{t-1}+N_{t}
$$

if new members $N_{t}$ are allowed in the year $t$. This population status is updated throughout the planning horizon.

\section{Actuarial risk}

According to [16], one type of actuarial risk is the longevity risk. This is the risk that a retiree of the fund lives longer than may be expected on the basis of mortality rates. This type of risk is concerned with old age pensions. Longevity is a high-profile risk for defined benefit pension schemes. Another actuarial risk is the lower asset value interest rates with raised value of liabilities. 


\subsubsection{Policies and regulations}

Most of the pension fund activities are restricted by policies and regulations. Whether the scheme is defined contribution or defined benefit, still there are restrictions on how members contribute, paid benefits as well as investment processes.

\section{Contribution policies}

According to [16], the management of a pension fund can not only manage its liabilities, also the assets can be managed. One of the instruments to manage the assets is by means of the contribution policy. In the contribution policy, the system is chosen on which the level of the contribution rate is determined. Most pension funds use a dynamic contribution rate. In this system, the level of the contribution rate can be modified in the course of time. If the investment or demographic profile is adverse, the contribution rate may be increased otherwise it may be decreased [15]. An increase of contribution rate by active members means that cash inflows are higher for the fund. The asset liability management problem objective can be to minimize contribution rate as in [31].

\section{Liabilities}

Liability is the present value of expected future benefit payments. According to [42], each pension fund has a series of cash flows it expects to pay out in future to its existing members. Future payment depends on the longevity and possible earlier retirement of the members, salary growth rates, wage inflation and price inflation. The world populations are aging, having more retirees that live longer due to improved living standards and medical services. Pension funds estimate their liability for a planning horizon up to 100 years. Liability is discounted to determine their present value.

\section{Asset value}

This is the value of asset converted to the market value used to measure the solvency. The ratio of asset value to liabilities can be used to measure the solvency of the fund. Referring to [16], the ratio of asset value to liabilities is called funding ratio. If the funding ratio is equal to $100 \%$, it implies that asset value matches exactly liabilities. But if the funding ratio is less than $100 \%$, it is called underfunding. This means asset value can not cover all liabilities. In this situation, a sponsor of the fund should make extra contribution to cover the deficit.

If the funding ratio is greater than $100 \%$, it is called overfunding. In this case, the fund makes the surplus and this is favorable. Using funding ratio in asset liability management problems, a greater value of funding ratio is set to make sure that the model preferences assets with the best return and will create a surplus. 


\section{Cash flow policies}

Cash flow policies guarantee that the total expenditures do not exceed revenues [23]. Cash flow is the net amount of cash moving into and out of a fund. Positive cash flow indicates that a fund's asset value is increasing and the fund reinvest it in financial markets. Negative cash flow indicates that a fund's asset value is decreasing. In asset liability management, the cash inflow is from contributions, from selling asset investments, from returns of asset investments and from other sources allowed by regulations. The cash outflow is to benefit payments, to buying of asset investment and to others allowed by regulations. Selling and buying of assets are also associated with transaction costs.

\section{Investment policies}

The value of the assets is also influenced by the investment policies. In these policies, the management of the pension fund decides in which asset categories the fund invests its assets. Also the levels of the lower and upper bounds on the fraction of the total assets invested in each asset class, and rules concerning rebalancing are part of the investment policy [16]. These rules specify the allowed investment in order to foster the diversification of asset investment to avoid risk.

\subsection{Pension system in Tanzania}

As mentioned in Subsection 1.2, Tanzania mainland pension system comprises of five public pension funds. The system is mostly restricted to the formal sector. According to SSRA 2014/2015 annual report, it covers around 2,142,350 members which is only about $4 \%$ of the whole population and $10 \%$ of the working population. Up to 2014, all funds except PPF were converted to PAYG DB [38].

The SSRA was established under Cap. 139 of the social security regulatory authority act No. 8 of 2008 as amended by act No. 5 of 2012, with the main objective of supervising and regulating the social security sector. The SSRA started its operations at the end of the year 2010. In light of its legal mandate as provided in the social security act, it is charged with the role of regulating and supervising the provisions of social security services in the country. Every pension fund is under the management of the board of the respective fund. SSRA may set contribution rates payable to the fund by members and minimum benefit payable to the beneficiaries. But before adjusting contribution rate and minimum benefit payable, this authority should undertake or cause a fund to undertake valuation of assets to the liabilities. Currently, contribution rate is $20 \%$ with $10 \%$ from an employee and $10 \%$ from employer or $5 \%$ to $15 \%$ from an employee and employer, respectively.

These funds offer different kinds of benefits, short term and long term. Two of them, commuted and monthly pension are used in this thesis. Commuted benefit is a part of pension converted as the amount payable in the future stream to present value terms as a lump sum at retirement. The 
monthly benefit is the part of pension converted as regular monthly payments payable after retirement on the condition of retiree survival. A member who attains the age fifty-five years may at any time thereafter opt to retire but if he does not, he shall continue to be a member until he attains the compulsory retirement age of sixty. The qualifying period for a member to receive pension is 15 years or 180 months of contributing provided a member has met other conditions set in the enabling legislation of the respective fund and attained the retirement age. No early retirement benefit is paid for mandatory defined pension funds. The current benefit formula was issued in 2014 by SSRA and aims to offer a benefit of $25 \%$ of highest average final salary for all contributing months of beneficiary at retirement and not less than $40 \%$ of the prescribed lowest sectorial minimum wage after retirement. The authority may where necessary, set rates of indexation of members benefit to the current level of earnings of contributors.

In 2015, pension funds investment had grown up to 7.8 trillion Tanzania shillings or approximately to 31.4 million SEK . The Bank of Tanzania in consultation with SSRA issues guidelines regarding pension funds investment activities. These guidelines prescribe limits for investments in various asset categories to foster risk diversification and limit the excessive concentration of risk. The recent social security schemes investment guidelines were issued by Bank of Tanzania in 2015. Pension funds may invest in the following asset categories: fixed deposits, government securities, corporate bonds, loans to the government, loans to corporate and cooperative societies, equities, properties and licensed collective schemes. A pension fund may exceed these limits in the event of an increase in the market price of assets, revaluation, bonus issues or transfer of investment from one category to another provided that, no new investment shall be done for those categories until such times, when the investments are restored to the limits prescribed in the guidelines. Such excess should be reported immediately to Bank of Tanzania. 


\section{Literature review}

\subsection{Stochastic programming}

Stochastic programming is a mathematical approach which solves decision problems which involve uncertain data. It was introduced by [13], [4] and others during the 1950's. Stochastic programming is an extension of linear and nonlinear programming to decision models where the coefficients are not known at the time of making a decision. In this approach, unknown coefficients are treated as random parameters with known probability distributions which are independent of the decision taken.

There are several formulations of stochastic programming used in asset liability management for pension funds. These are two-stage, multistage, and risk constrained stochastic programming.

\subsubsection{Two-stage stochastic programming}

In this formulation, the decision process is divided into two stages. A first stage which is a number of decisions to be taken before the random realizations. Decisions taken after the random realizations are called second stage decisions. Then, the process goes on by forming the sequence of decision up to the horizon. The sequence of decisions are represented as

$$
x \rightarrow \xi(\omega) \rightarrow y(\omega, x) .
$$

A classical two-stage stochastic linear programming with recourse is the problem of finding

$$
\begin{array}{r}
\min z=c^{T} x+E_{\xi}\left[\min q(\omega)^{T} y(\omega)\right] \\
\text { s.t. } \quad A x=b, \\
T(\omega) x+W y(\omega)=h(\omega), \\
x \geq 0, y(\omega) \geq 0 .
\end{array}
$$

A first stage decisions are represented by the $n_{1} \times 1$ vector $x$. The first stage vectors and matrices corresponding to $x$ are $c, b$, and $A$. In the second stage a number of random realization $\omega \in \Omega$ may 
be revealed. For a given realizations $\omega$, the second stage problem data $q(\omega), h(\omega)$ and $T(\omega)$ become known.

In [27], two-stage stochastic programming is used for asset liability management for a Malaysian pension fund.

\subsubsection{Multistage stochastic programming}

In stochastic programming models, the uncertain data $\xi_{1}, \ldots, \xi_{T}$ is revealed gradually over time, in $T$ periods, and our decisions should be adapted to this process. The decision process has the form

decision $\left(x_{1}\right) \leadsto \operatorname{observation}\left(\xi_{2}\right) \leadsto \operatorname{decision}\left(x_{2}\right) \leadsto \ldots \leadsto \operatorname{observation}\left(\xi_{T}\right) \leadsto \operatorname{decision}\left(x_{T}\right)$.

Reference to [43], at time $t$, a decision $x_{t}=\left(x_{1 t}, \ldots, x_{n t}\right)$ is a function $x_{t}=x_{t}\left(\xi_{[t]}\right)$ of available information given by realization data $\xi_{[t]}=\left(\xi_{1} \ldots, \xi_{t}\right)$ of the data process up to time $t$. The multistage stochastic programming problem is in the following form,

$$
\begin{aligned}
& \min _{x_{1}, x_{2}, . ., x_{T}} E\left[f_{1}\left(x_{1}\right)+f_{2}\left(x_{2}\left(\xi_{[2]}\right), \xi_{2}\right)+\ldots+f_{T}\left(X_{T}\left(\xi_{[T]}\right), \xi_{T}\right)\right] \\
& \text { s.t. } \\
& x_{1} \in \chi_{1}, x_{t}\left(\xi_{[t]}\right) \in \chi_{t}\left(x_{t-1}\left(\xi_{[t-1]}\right), \xi_{t}\right), \quad t=1, \ldots, T-1,
\end{aligned}
$$

where the set $\chi_{1} \subset \mathbb{R}^{n}$ are deterministic at $t=0$ and set $\chi_{t} \subset \mathbb{R}^{n}$ are decision variables at $t=1, \ldots, T-1$.

Several recent studies have been conducted for asset liability management for pension funds using multistage stochastic programming. Among these are, [1] and [23] for a Finnish insurance pension company, [31] for a Dutch pension fund, [19] for a Austrian pension fund, and [18] for a Czech pension funds.

\subsubsection{Risk constrained}

In this approach, the stochastic programming model incorporates risk constraints. The risk concerns a loss or failing to reach a target due to decisions and realizations of the uncertain data. Two kinds of risk constraint that used in asset liability management for pension funds by stochastic programming are discussed. These are CVaR constraints and Integrated chance constraints. 


\section{CVaR constraints}

Conditional value at risk ( $\mathrm{CVaR})$ is a risk assessment technique often used to reduce the probability that a portfolio will incur large losses. CVaR is also known as mean excess loss, mean shortfall, tail Var, average value at risk, or expected shortfall. CVaR was created to serve as an expansion of value at risk $(\mathrm{VaR})$ and is a more consistent measure of risk than VaR.

Following [39] and [40], assume $f(x, y)$ to be the loss associated with decision vector $x$, which belongs to a certain subset $X$ of $\mathbb{R}^{n}$ and the random vector $y$ in $\mathbb{R}^{m}$. The vector $x$ is interpreted as representing a portfolio, with $X$ as the set of the available portfolios (subject to various constraints). The vector $y$ stands for the uncertainties, e.g., in market parameters, that can affect the loss.

For each $x$, the loss $f(x, y)$ is a random variable having a distribution in $\mathbb{R}$ induced by that of $y$. The underlying distribution of $y$ in $\mathbb{R}^{m}$ which is assumed for convenience to have density, $p(y)$. The probability of loss function $f(x, y)$ not exceeding a threshold $\alpha$ is given by

$$
\Psi(x, \alpha)=\int_{f(x, y) \leq \alpha} p(y) d y .
$$

As a function of $\alpha$ for fixed $x, \Psi(x, \alpha)$ is the cumulative distribution function for the loss associated with $x$. It determines the behavior of this random variable $f(x, y)$ and is fundamental in defining VAR and CVaR.

The $\beta$-VaR and $\beta$-CVaR values for the loss random variable associated with $x$ and any specified probability level $\beta$, will be denoted by $\alpha_{\beta}(x)$ and $\phi_{\beta}(x)$, and defined as

$$
\alpha_{\beta}(x)=\min \{\alpha \in \mathbb{R}: \Psi(x, \alpha) \geq \beta\}
$$

and

$$
\phi_{\beta}(x)=\frac{1}{1-\beta} \int_{f(x, y) \leq \alpha_{\beta}(x)} f(x, y) p(y) d y .
$$

In equation 3.8, $\alpha_{\beta}(x)$ comes as the left end point of the nonempty interval consisting of the values $\alpha$ such that $\Psi(x, \alpha)=\beta$. In equation 3.9, the probability that $f(x, y) \geq \alpha_{\beta}(x)$ is therefore equal to $1-\beta$. Then $\phi_{\beta}(x)$ becomes the conditional expectation of the loss associated with $x$ relative to that loss being $\alpha_{\beta}(x)$ or greater.

The key to this approach is characterization of $\alpha_{\beta}(x)$ and $\phi_{\beta}(x)$ in terms of a function $F_{\beta}$ on $X \times \mathbb{R}$. The function $F_{\beta}$ is convex and differentiable and defined as

$$
F_{\beta}(x, \alpha)=\alpha+\frac{1}{(1-\beta)} \int_{y \in \mathbb{R}^{m}}[f(x, y)-\alpha]^{+} p(y) d y,
$$


where $[t]^{+}=t$ when $t>0$ but $[t]^{+}=0$ when $t \leq 0$.

Furthermore, the integral in (3.10) of $F_{\beta}$ can be approximated in various ways. For example, this can be done by sampling the probability distribution of $y$ according to its density $p(y)$, such that the sampling generates a collection of vectors $y_{1}, y_{2}, \ldots, y_{I}$. Then the corresponding approximation to $F_{\beta}$ is

$$
\widetilde{F}_{\beta}(x, \alpha)=\alpha+\frac{1}{I(1-\beta)} \sum_{k=1}^{I}[f(x, y)-\alpha]^{+} .
$$

The expression $\widetilde{F}_{\beta}(x, \alpha)$ is convex and piecewise linear with respect to $\alpha$. The important advantage of using CVaR as a risk measure is that its structure does not destroy the linear structure of the models. Also, it is a subadditive measure of risk [40].

Studies of asset liability management using CVaR constraints are [8] for a Dutch pension fund and [2] for a Chinese pension fund.

\section{Integrated chance constraints}

Integrated chance constraints (ICC) was firstly introduced by Haneveld [20] and the concept based on chance (probabilistic) constrained programming. ICC has advantages compared to chance constraints especially in wealth problems where the mean risk shortage is more appropriate than the probability risk of shortage, as used in chance constraints. ICC gives convex optimization problems, for all distribution of random coefficients involved.

As in [20] and [22], consider a linear program with random constraints,

$$
\begin{aligned}
& \min z=c^{T} x \\
& \text { s.t. } \\
& T(\omega) x=h(\omega), \\
& x \in X,
\end{aligned}
$$

where $X=\left\{x \in \mathbb{R}_{+}^{n} ; A x=b\right\}$ is shorthand for the usual deterministic constraints and nonegativity restrictions. The $m$ random constraints $T_{i}(\omega) x=h_{i}(\omega), i \in I=\{1, . ., m\}$, represent different goals. The aim is to satisfy each of these linear constraints. However, at the time where $x$ needs to be decided, the actual values of the matrix $T(\omega)$ and right-hand side $h(\omega)$ are not known, because they depend on the underlying random vector $\omega$. Only probabilistic information on $\omega$ is known, by assumption that the distribution of $\omega$ is given.

Consider the deviation $\eta_{i}(x, \omega)=T_{i}(\omega) x-h_{i}(\omega), i \in I$ with surpluses $\eta_{i}(x, \omega)^{+}=\max \left\{0, \eta_{i}(x, \omega)\right\}$ and shortages $\eta_{i}(x, \omega)^{-}=\max \left\{0,-\eta_{i}(x, \omega)\right\}$. If the random constraints in (3.12) are replaced 
by chance constraints, then it is assumed that surplus is accepted but the shortage is restricted. Individual chance constraint is

$$
P\left\{\eta_{i}(x, \omega)^{-}>0\right\} \leq \alpha_{i}, \quad i \in I
$$

and a joint chance constraints is

$$
P\left\{\max _{i \in I}\left(\eta_{i}(x, \omega)^{-}\right)>0\right\} \leq \alpha,
$$

where $\alpha_{i}$ and $\alpha$ are risk parameters. Interpretation of chance constraints is that a solution $x \in X$ is feasible only if it is not too risky.

In particular, the penalty cost or, more generally, the recourse approach is based on a quantitative risk concept, whereas chance constraints are defined in terms of qualitative risk concept. Hence the alternative quantitative risk measure to traditional chance constraints is ICC defined as

$$
\mathbb{E}_{\omega}\left[\eta_{i}(x, \omega)^{-}\right] \leq \beta_{i}, \quad \beta_{i} \geq 0,
$$

corresponding to individual chance constraint, and

$$
\mathbb{E}\left[\max _{i \in I}\left(\eta_{i}(x, \omega)^{-}\right)\right] \leq \beta, \beta \geq 0,
$$

as an alternative to joint chance constraint. The risk aversion parameters $\beta_{i}$ and $\beta$ represent the largest acceptable expected shortfall to be specified by the decision maker.

The name integrated chance constraints refers to the fact that, due to partial integration with $F_{\eta_{i}}(\tau ; x)$ the distribution function of $\eta_{i}(\omega, x)$,

$$
\begin{aligned}
\mathbb{E}_{\omega}\left[\eta_{i}(x, \omega)^{-}\right] & =\int_{-\infty}^{0}-\tau d F_{\eta_{i}}(\tau ; x) \\
& =\underbrace{-\tau F_{\eta_{i}}(\tau ; x)}_{=0}]_{-\infty}^{0}+\int_{-\infty}^{0} F_{\eta_{i}}(\tau ; x) d \tau . \\
& =\int_{-\infty}^{0} P\left\{\eta_{i}(x, \omega)<\tau\right\} d \tau .
\end{aligned}
$$

Some recent studies in this area are [21] for a Dutch pension funds and [27] for a Malaysian pension fund.

\subsection{Scenario tree}

Stochastic programming always describes uncertain parameters using a scenario tree [37]. The scenario tree is a tree that branches off every random variable $\xi_{t}$ in each stage $t$. This approach requires finite discrete distributions. Consider Figure 3.1 with time horizon $T=3,6$ scenarios and 
10 nodes. Each scenario $s=s_{1}, s_{2}, s_{3}, s_{4}, s_{5}, s_{6}$ begins from the same node $n_{1}$ at stage 1 , and ends at a leaf node at the horizon. The branches emanating from a node represent the realizations of a random event at that stage. The process continues until the end of the time horizon so that each scenario is the complete path from the initial node up to the leaf node. Each scenario is associated by a probability $p(\omega)$.

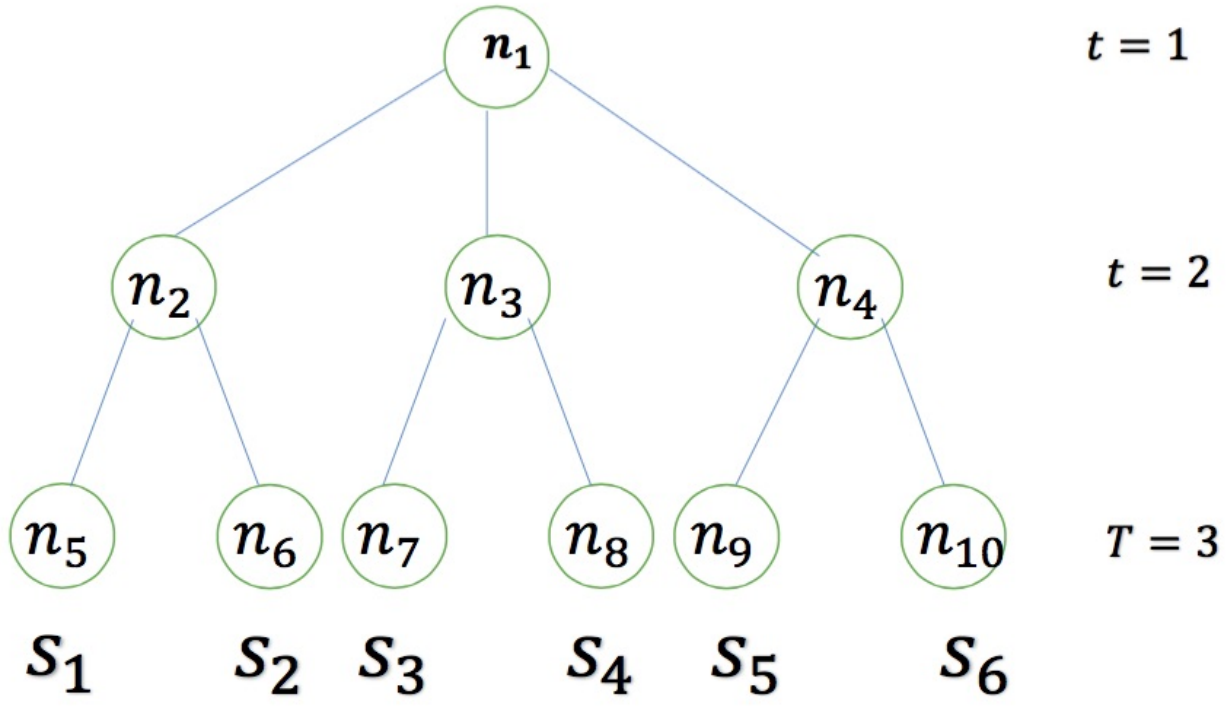

Figure 3.1: Scenario tree for 3 stages, 6 scenarios and 10 nodes

The basic concepts of scenario trees are structure, the horizon, a stage, and the method of generating the scenario tree.

\subsubsection{Structure}

There is no theoretical rule for the structure of a scenario tree [17]. Everyone chooses according to the nature of the problem, with regulations and rules considering no arbitrage properties. In [19], it is commented that using only a few branches and fitting distributions across all nodes may induce (unintended) serial correlation between stages. This problem may be avoided by using many 
branches. In [13], it is remarked that a set of 5000 scenarios has proven to be adequate for investors interested in standard risk-reward analysis, such as efficient frontier. The important thing is the computational limitation and available computer software, since the exponential growth of the tree may cause computational intractability.

\subsubsection{Time horizon}

The time horizon is the whole interval of the decision process, $t=1, \ldots, T$. The decision process can go up to time $T$ or $T-1$. The stage lengths are not necessarily equal, and for a chosen time horizon, the crucial step is to relate the time instants and stages. Some recommendation is common for financial applications, e.g., accept unequal lengths of the period between subsequent stages, starting with a short first period. The main limitations on the number of stages are due to numerical tractability [17].

The planning horizon for most pension fund stretches out for decades, as a result of the long commitment to pay a benefit to retirees. For most researchers, the horizon is guided by the nature of the fund (policies and regulations) and available data [18]. In other cases, horizons are obtained by application of heuristic rules and/or experience, taking into account limitations due to numerical intractability [17].

\subsubsection{Stage}

Basic concepts for stochastic programming is decision stages $t$, where $t$ goes up to the time horizon $T$. The stage is the time point at which the decision is taken. The first stage decisions consist of all decisions that have to be selected before further information is revealed whereas the second stage decisions are allowed to adapt to this information, and so forth. Stages do not necessarily refer to the time periods but they correspond to steps in the decision process.

\subsubsection{Method}

The performance of a stochastic programming model depends on the scenario generation method. There are several methods used in asset liability management for pension funds by stochastic programming.

\section{Moment Matching}

This method was introduced by Høyland and Wallace in [25] and [24]. Moment matching is a generic estimation technique, whereby we do not assume knowledge of a random variable's probability distribution function. A method based on non-linear programming. It is used to generate a 
limited number of discrete outcomes that satisfy specified statistical properties. Users are free to specify any statistical properties they find relevant, and the method can handle inconsistencies in the specifications. The basic idea is to minimize some measure of distance between the statistical properties of the generated outcomes and the specified properties.

Let $S$ be the set of all specified statistical properties, and $S_{V A L_{i}}$ be the specified value of statistical property $i$ in $S$. Moreover, let $I$ be the number of random variables, $M$ is the matrix of zeros and ones, $p$ is the probability vector, $x$ is the outcome vector, and $\omega_{i}$ is the weight of statistical property. The mathematical expression $f_{i}(x, p)$ for statistical property $i$ in $S$ is generally described by the equation

$$
\begin{array}{r}
\min _{x, p} \sum_{i \in S} \omega_{i}\left(f_{i}(x, p)-S_{V a l_{i}}\right)^{2}, \\
\sum p M=1, \\
p \geq 0,
\end{array}
$$

which minimizes the distance between the statistical properties of the constructed distribution and the specification, subject to constraints defining the probabilities to be nonnegative and to sum up to one.

In [31], scenario generation methods are developed and tested. The tree fitting method based on Høyland and Wallace in [25] slightly outperform the random sampling and adjusted random sampling. In [18], they apply the moment fitting method of Høyland and Wallace in [24] to create a scenario tree for returns of the considered assets classes. The procedure is based on goal programming ideas where weighted squares of distances between the required values of moments of assets

returns (e.g., mean, variance, skewness and kurtosis of the marginal probability distributions and both the in- and inter-stage correlations) and moments computed for the approximating discrete probability distribution are minimized.

In [19], the Innovest for Austrian pension fund financial planning model in InnoALM is developed. The scenarios in InnoALM are defined in terms of the distribution of asset returns and their first and second order moments. The latter can be prespecified by the user or estimated from the built in database of historical returns.

\section{Sampling Methods}

A commonly used technique in generating discrete samples from a continuous distribution is to use Monte Carlo sampling where uniformly distributed pseudo-random numbers are appropriately transformed to the target distribution. However, in asset liability management applications, we can computationally only afford a small sample size and inevitably face the sampling error problem. In [23], Monte Carlo sampling methods based on [12] is used to solve a stochastic programming 
model for a Finnish pension company. They compared optimal values obtained by a Monte Carlo sampling and Sobol sequence which is a special case of Quasi Monte Carlo sampling method. The optimal value obtained by using Sobol converges faster than the optimal value obtained by using Monte Carlo sampling. This is due to the reason that Quasi Monte Carlo sampling methods have very good convergence properties. Monte Carlo based methods are in detail discussed in [12]

In [31], random sampling and adjusted random sampling methods were considered. The resulting scenario tree are used to solve an asset liability management model for a Dutch pension fund. Stochastic parameters are estimated by a vector autoregressive time series model. Random sampling method based on sampling from the error distribution of the estimated vector autoregressive model.

Adjusted random sampling method modifies a random sampling by matching the moments of an assumed underlying distribution. An adjusted random sampling method based on antithetic sampling in order to fit every odd moment of the underlying distribution of the stochastic parameters by assuming an even number of the underlying distribution of the stochastic parameters by assuming an even number of clusters in the scenario tree. In [31], it is commented that adjusted random sampling method can improve outcomes relative to the using of random samples alone. Adjusted random sampling method is based on the work by [10].

\section{Other method}

CAP:Link is a stochastic economic projection model. This model is used to generate economic factors and asset returns via a set of representative scenarios. Each scenario depicts a coherent set of outcomes. The projection span a long-run horizon of 10 to 40 years. Risks and rewards for alternative investment strategies are determined via dynamic asset and liability allocation over the scenarios [34]. CAP:Link was used to solve an asset and liability management system for Towers Perrin-Tillinghast company [35]. 



\section{Concluding Remarks}

This chapter gives the summary and conclusion of the thesis and future research.

\subsection{Summary}

Our problem is for a pay-as-you-go defined benefit Tanzania pension fund. The fund gives a final salary defined benefit.

- In paper 1: Even though several reforms have been taken by the Government to improve the sector, still it will not be sustainable in a long future. Evaluation of some suggested reforms show that they cannot guarantee a long-term sustainability.

On the other hand, by considering investments of assets which give higher returns, the study shows that the asset value can be increased towards liabilities. But contributions can still not cover benefit payouts.

- In paper 2: Two stochastic programming models for Tanzania pension funds are built using the existing regulations and policies, according to current and modified investment guidelines. The asset categories used are Government security, real estate, loans and fixed deposits with their corresponding returns from NSSF.

It is shown that, as the old age population increases too much in relation to the number of contributing members, the pension payments exceed the contributions, and the asset value are used to pay benefits instead of investing for covering future liabilities. Our study suggests that in order to improve the long-term sustainability of the Tanzania pension fund system, it is necessary to make reforms concerning contribution rate and investment guidelines. Also the authority should formulate condition for the solvency of funds. This must be done by setting the higher goals that will make the fund to improve their performance and maintaining sustainability. 


\subsection{Future research}

- From paper 1: The projections with different assumptions about life expectancy and population growth, to see how stable the conclusions are. Also, reforms of the system will be studied. The shifting of the system from pay-as-you-go defined benefit to pay-as-you-go defined contribution will be analyzed with reference to other countries which have reformed their systems.

- From paper 2: Other forms of stochastic programming will be studied. The model will be improved by considering other scenario generation methods. Real data of status of members of pension funds will be used. The study will also include other variables used by Tanzania pension funds, e.g., administrative cost. 


\section{Bibliography}

[1] Ainassari, K. K. M. and Ranne, A. (1998). Selecting an Optimal Investment Portfolio for a Pension Insurance Company. 8th AFIR Colloquium, 7-23.

[2] Bai, M. and Ma, J. (2009). The CVaR Constrained Stochastic Programming ALM Model for Defined Benefit Pension Funds. International Journal of Modelling, Identification and Control, $8(1): 48-55$.

[3] Batini, N., Callen, T., and McKibbin, W. J. (2006). The Global Impact of Demographic Change. IMF Working Paper, 06/9.

[4] Beale, E. (1955). On Minimizing a Convex Function Subject to Linear Inequalities. Royal Statistical Society. Series B (Methodological), 1:173-184.

[5] Birge, J. R. and Louveaux, F. (2011). Introduction to Stochastic Programming. Springer Science \& Business Media.

[6] Bloom, D., Boersch-Supan, A., McGee, P., and Seike, A. (2011). Population Aging: Facts, Challenges, and Responses. Benefits and Compensation. Working Paper Series, 41(1):22.

[7] Bloom, D., Canning, D., Mansfield, R., and Moore, M. (2007). Demographic Change, Social Security Systems, and Savings. Journal of Monetary Economics, 54(1):92-114.

[8] Bogentoft, E., Romeijn, E., and Uryasev, S. (2001). Asset/Liability Management for Pension Funds using Cvar Constraints. Risk Finance, 3(1):57-71.

[9] Börsch Supan, A. (2005). From Traditional DB to Notional DC Systems: The Pension Reform Process in Sweden, Italy, and Germany. Journal of the European Economic Association, 3.25:458-465.

[10] Carino, D. R., Kent, T., Myers, D. H., Stacy, C., Sylvanus, M., Turner, A. L., Watanabe, K., and Ziemba, W. T. (1994). The russell-yasuda kasai model: An asset/liability model for a japanese insurance company using multistage stochastic programming. Interfaces, 24(1):29-49.

[11] Carol, B., Sharon, Y., and Anne, L. (1999). Demographic Comparisons of Aging in Five Selected Countries. Journal of Family and Economic Issues, 20(3):223-250.

[12] Chiralaksanakul, A. (2003). Monte Carlo Methods for Multi-stage Stochastic Programs. Ph.D thesis, University of Texas at Austin, Austin, Texas.

[13] Dantzig, G. (1955). Linear Programming under Uncertainty. Management Science, 1(3-4):197206.

[14] Dert, C. (1995). Asset Liability Management for Pension Funds: A Multistage Chance Constrained Programming Approach. Ph.D thesis, Erasmus University Rotterdam.

[15] Dickson, D. C., Hardy, M. R., and Howard, R. W. (2013). Actuarial Mathematics for Life Contingent Risks. Cambridge University Press.

[16] Drijver, S. J. (2005). Asset Liability Management for Pension Funds using Multistage MixedInteger Stochastic Programming. Ph.D thesis, University Library Groningen. 
[17] Dupačová, J. (2002). Applications of Stochastic Programming: Achievements and Questions. European Journal of Operational Research, 140(2):281-290.

[18] Dupačová, J. and Polívka, J. (2009). Asset-Liability Management for Czech Pension Funds using Stochastic Programming. Annals of Operations Research, 165(1):5-28.

[19] Geyer, A. and Ziemba, W. T. (2008). The Innovest Austrian Pension Fund Financial Planning Model InnoALM. Operations Research, 56(4):797-810.

[20] Haneveld, K. (2013). In Lecture Notes in Economic and Mathematical System: Duality in Stochastic Linear and Dynamic Programming, volume 274. Berlin:Springer.

[21] Haneveld, W. K. K., Streutker, M. H., and Vlerk, M. H. V. D. (2010). An ALM Model for Pension Funds using Integrated Chance Constraints. Annals of Operations Research, 177(1):4762.

[22] Haneveld, W. K. K. and Vlerk, H. V. D. (2006). Integrated Chance Constraints: Reduced Forms and an Algorithm. Computational Management Science, 3(4):245-269.

[23] Hilli, P., Koivu, M., Pennanen, T., and Ranne, A. (2007). A Stochastic Programming Model for Asset Liability Management of a Finnish Pension Pompany. Annals of Operations Research, 152(1):115-139.

[24] Høyland, K. and Wallace, S. (2001). Generating Scenario Trees for Multistage Decision Problems. Management Science, 47(2):295-307.

[25] Høyland, K. and Wallace, S. W. (1996). Generating Scenario Trees for Multi Stage Decision Problems. Department of Economics and Technology Management, Norwegian University of Science and Technology.

[26] Humberto, G., Maria, D., and Steven, H. (2016). Optimal Strategies for Pay-As-You-Go Pension Finance: A Sustainability Framework. Insurance: Mathematics and Economics, 69:117126.

[27] Hussin, S. A. S., Mitra, G., and Roman, D. (2014). An Asset and Liability Management (ALM) Model using Integrated Chance Constraints. AIP Conference Proceedings, 1635(1).

[28] Isaka, I. (2016). Updates on Social Security Reforms in Tanzania. Presentation in NBAA Seminar on Social Security Schemes.

[29] Jing, A., Patrick, L., and Allen, F. (2015). A New Defined Benefit Pension Risk Measurement Methodology. Insurance: Mathematics and Economics, 63:40-51.

[30] Johnson, R. (2004). Economic Policy Implications of World Demographic Change. Economic Review-Federal Reserve Bank of Kansas City, 89(1):39.

[31] Kouwenberg, R. (2001). Scenario Generation and Stochastic Programming Models for Asset Liability Management. European Journal Operational Research, 134(2):279-292.

[32] Lui, F. T. (1998). Retirement Protection: A Plan for Hong Kong. ( $1^{s} t$ Edition). City University of Hong Kong Press.

[33] Mettler, U. (2005). Projecting Pension Fund Cash Flows. Technical Report 1, National Centre of Competence in Research Financial Valuation and Risk Management, Zurich. 
[34] Mulvey, J. M. (1996). Generating Scenarios for the Towers Perrin Investment System. Interfaces, 26(2):1-15.

[35] Mulvey, J. M., G, G., and Morgan, C. (2000). An Asset and Liability Management System for Towers Perrin-t Tillinghast. Annals of Operations Research, 30(1):96-114.

[36] Mylonas, P. and Maisonneuve, C. d. L. (1999). The Problems and Prospects Faced by PayAs-You-Go Pension Systems. Economics Department Working Paper 215, OECD, Paris.

[37] Pflug, G. C. and Pichler, A. (2014). Multistage Stochastic Optimization. Springer.

[38] PolicyNote (2014). Public Expenditure Review: Government Pension Obligations and Contingent Liabilities. World Bank Technical document.

[39] Rockafellar, R. T. and Uryasev, S. (2000). Optimization of Conditional Value-at-Risk. Journal of Risk, 2:21-42.

[40] Rockafellar, R. T. and Uryasev, S. (2002). Conditional Value-at-Risk for General Loss Distributions. Journal of Banking and Finance, 26(7):1443-1471.

[41] Ronald, L. (2003). The Demographic Transition: Three Centuries of Fundamental Change. The Journal of Economic Perspectives, 17(4):167-190.

[42] Schwaiger, K., Lucas, C., and Mitra, G. (2007). Models and Solution Methods for Liability Determined Investment. Report, CARISMA, Brunel University.

[43] Shapiro, A., Dentchera, D., and Ruszczynski, A. (2009). Lecturers on Stochastic Programming: Modeling and Theory. Mathematical Programming Society, Philadephia. 

PART II 


\section{Papers}

The papers associated with this thesis have been removed for copyright reasons. For more details about these see:

http://urn.kb.se/resolve?urn=urn:nbn:se:liu:diva-147853 